\title{
Pengaruh Kebiasaan Sarapan Dan Status Gizi Remaja Terhadap Prestasi Belajar
}

\author{
Rifatul Masrikhiyah*1 Mohammad Iqbal Octora ${ }^{2}$ \\ ${ }^{1,2}$ Program Studi Ilmu Gizi, Fakultas Ilmu Kesehatan, Universitas Muhadi Setiabudi Brebes, Indonesia \\ e-mail: "rifatul.masrikhiyah@gmail.com, m.octora@mhsumus.ac.id
}

\begin{abstract}
ABSTRAK
Tujuan dari penelitian ini adalah untuk mengetahui hubungan antara kebiasaan sarapan dan status gizi anak usia sekolah dengan prestasi belajar siswa SMP N 02 Songgom. Desain penelitian dalam penelitian ini adalah crossectional. Populasinya adalah semua siswa kelas VII. di SMP N 2 Songgom, sedangkan sampel penelitian ini yaitu siswa SMP N 02 Kelas VII A dan VII E sebanyak 60 anak. dengan menggunakan teknik pengambilan sampel secara random sampling. Pengumpulan data untuk kebiasaan sarapan menggunakan kuesioner sedangkan status gizi dilihat dari nilai IMT anak yang didapat dari pengukuran berat badan dan tinggi badan siswa SMP N 02 Songgom. Data prestasi belajar siswa merupakan data sekunder yang diperoleh dari nilai raport siswa. Analisis menggunakan uji chi Square untuk mengetahui hubungan antara variabel dependent dan variabel independent. Hasil penelitian diperoleh siswa dengan kebiasaan sarapan dan status gizi yang baik memiliki tingkat prestasi yang baik. Kesimpulan dalam penelitian ini yaitu terdapat hubungan kebiasaan sarapan $(P<0,005)$ dan status gizi $(p<0,005)$ terhadap prestasi belajar siswa di SMP N 02 Songgom. Kekuatan hubungan antara kebiasaan sarapan dengan prestasi belajar siswa sebesar 2,34 yang artinya siswa yang memiliki kebiasaan sarapan yang baik memiliki peluang mendapatkan prestasi belajar siswa yang baik 2,34 kali lebih baik dibandingkan siswa yang kebiasaan sarapannya kurang. Kekuatan hubungan antara status gizi dengan prestasi belajar siswa sebesar 1,56 yang artinya siswa yang memiliki status gizi normal memiliki peluang mendapatkan prestasi belajar siswa yang baik 1,56 kali lebih baik dibandingkan siswa yang kebiasaan sarapannya kurang.
\end{abstract}

Kata kunci: Sarapan, Prestasi Belajar, Status Gizi

\begin{abstract}
The purpose of this study is to find out the relationship between breakfast habits and the nutritional status of school-age children with the learning achievements of Songgom Junior High School students. The design of the research in this study is crossectional. The population is all grade VII students. in SMP N 2 Songgom, while this research sample is junior high school students N 02 Grades VII A and VII E as many as 60 children. using random sampling techniques. Data collection for breakfast habits using questionnaires while nutritional status is seen from children's BMI scores obtained from weight and height measurements of Junior High School students N 02 Songgom. Student learning achievement data is secondary data obtained from students' raport scores. The analysis used the chi Square test to find out the relationship between dependent variables and independent variables. The results of the study obtained students with breakfast habits and good nutritional status had good performance levels. The conclusion in this study is that there is a relationship of breakfast habits $(P<0.005)$ and nutritional status $(p<0.005)$ to the learning achievement of students at SMP N 02 Songgom. The strength of the relationship between breakfast habits and student learning achievement is 2.34 which means students who have good breakfast habits have a 2.34 times better chance of getting good student learning achievement than students whose breakfast habits are lacking. The strength of the relationship between nutritional status and student learning achievement is 1.56 which means students who have normal nutritional status have a 1.56 times better chance of getting good student learning achievement than students whose breakfast habits are lacking.
\end{abstract}

Keywords: Breakfast, Learning Achievement, Nutritional Status

\section{PENDAHULUAN}

Anak usia sekolah adalah investasi bangsa, kelak mereka akan menjadi kader penerus pembangunan di Indonesia. Pemerintah harus berupaya untuk meningkatan kualitas sumber daya manusia sejak dini, baik dari segi kesehatan maupun kecerdasan secara sistematis dan 
berkesinambungan. Tumbuh kembang anak usia sekolah serta prestasi belajar memerlukan asupan zat gizi yang memadai, baik dari segi kuantitas maupun kualitas. Peningkatan prestasi belajar yang pada akhirnya dapat membawa dampak meningkatkan prestasi belajarnya dapat dicapai dengan berbagai cara, salah satunya adalah makan pagi atau biasa disebut dengan sarapan. Berdasarkan Riset Kesehatan Dasar 2010, 16,9\%-50\% anak usia sekolah dan remaja, serta ratarata $31,2 \%$ orang dewasa di Indonesia tidak biasa sarapan. Anak sekolah sekedar mengonsumsi minuman saat sarapan $(26,1 \%)$, seperti air putih, susu, atau teh dan 44,6\% mengonsumsi sarapan berkualitas rendah[1]. Makan pagi atau sarapan mempunyai peranan penting bagi anak sekolah usia 6-14 tahun, yaitu untuk pemenuhan gizi di pagi hari, dimana anak-anak berangkat ke sekolah dan mempunyai aktivitas yang sangat padat di sekolah. Apabila anak-anak terbiasa sarapan pagi, maka akan berpengaruh terhadap kecerdasan otak, terutama daya ingat anak sehingga dapat mendukung prestasi belajar anak ke arah yang lebih baik.

Sumber energi awal setiap orang harus memulai hari mereka dengan cukup energi sebagai modal untuk melakukan aktivitas, dimana pagi hari adalah start awal. Energi yang kita butuhkan tentunya berasal dari makanan apalagi setelah berjam-jam tidak ada asupan sama sekali. Sayangnya, banyak anak yang tidak melakukan sarapan pagi, mereka lebih memilih mengkonsumsi makanan jajanan di luar rumah atau di sekolah yang kualitas gizinya tidak terjamin. Makanan jajanan diluar seringkali tidak memperhatikan mutu gizi, kebersihan, dan keamanan pangan. Tidak sedikit masalah yang timbul akibat orang tua kurang peduli terhadap makanan yang dikonsumsi anak di sekolah. Makanan yang tidak aman dan tidak bergizi menimbulkan penyakit, seperti diare bahkan kanker dan dapat mengakibatkan tidak tercapainya angka kecukupan gizi.

Sarapan pagi merupakan pasokan energi untuk otak yang paling baik agar dapat berkonsentrasi di sekolah. Namun banyak anak yang tidak melakukan sarapan pagi, mereka lebih memilih mengkonsumsi makanan jajanan di luar rumah atau di sekolah yang kualitas gizinya tidak terjamin. Makanan jajanan diluar seringkali tidak memperhatikan mutu gizi, kebersihan, dan keamanan pangan. Tidak sedikit masalah yang timbul akibat orang tua kurang peduli terhadap makanan yang dikonsumsi anak di sekolah. Makanan yang tidak aman dan tidak bergizi menimbulkan penyakit, seperti diare bahkan kanker dan dapat mengakibatkan tidak tercapainya angka kecukupan gizi.

Sarapan juga mempengaruhi kinerja otak, makan pagi memiliki manfaat dalam memberi energi untuk otak, sarapan dapat membantu meningkatkan daya ingat dan konsentras[2][3]. Sarapan pagi merupakan makanan khusus untuk otak, makan pagi berkaitan erat dengan kecerdasan mental, artinya makan pagi memberikan nilai positif bagi aktivitas otak, otak dapat berfungsi secara optimal. Secara tidak langsung, dapat memberikan pengaruh positif terhadap diri manusia dalam menjalakan aktifitasnya sehari-hari.

Penelitian ini dilakukan dengan tujuan menggambarkan dan mendeskripsikan ada tidaknya hubungan antara kebiasaan makan pagi dengan prestasi belajar siswa. Melalui penelitian ini, diharapkan mampu mengungkap dan menjelaskan yang terjadi di lapangan, Berkaitan dengan pernyataan penelitian, bahwa kebiasaan makan pagi memberikan kontribusi yang positif bagi seseorang, terutama bagi anak sekolah.

\section{BAHAN DAN METODE}

Desain penelitian yang digunakan untuk mengetahui hubungan kebiasaan sarapan pagi dengan tingkat prestasi belajar pada anak adalah Crossectional. Pelaksanaan penelitian pada 31 Agustus 2019 pada anak kelas VIII A dan VIII E di SMP N 2 SONGGOM KEC. BREBES. Populasi yang digunakan dalam penelitian ini adalah seluruh siswa - siswi di SMPN 2 SONGGOM kelas VIII Kecamatan Songgom Kabupaten Brebes. Pada penelitian ini sampel yang diambil adalah siswa - siswi di SMP N 2 Songgom Kelas VIII A dan VIII E Kecamatan Songgom Kabupaten Brebes sejumlah 60 anak; dengan kata lain digunakan teknik Simple Random Sampling dalam penelitian ini. 
Variabel penelitian ini dapat dikategorikan dalam variabel dependen dan variabel independent. Variabel Independen dalam penelitian ini adalah kebiasaan sarapan pagi dan status gizi pada anak usia sekolah; sementara variabel dependen pada penelitian ini adalah tingkat prestasi belajar pada anak usia sekolah. Untuk mengetahui kebiasaan sarapan pagi pada anakanak, peneliti memberikan kuesioner, sedangkan status gizi diperoleh dengan cara melakukan pengukuran tinggi badan dan berat badan pada Anak usia sekolah. Data prestasi belajar siswa diperoleh dari nilai raport anak. Setelah Data terkumpul dari hasil pengumpulan data, langkah selanjutnya yang dilakukan oleh peneliti yaitu analisa data. Untuk mengetahui hubungan kebiasaan sarapan pagi dengan tingkat prestasi belajar pada anak usia sekolah menengah dengan analisis statistik inferensial dan menggunakan tabulasi silang. Selanjutnya untuk mengetahui hubungan korelasinya menggunakan Korelasi Spearman.

\section{HASIL DAN PEMBAHASAN}

Penelitian dilakukan pada 60 anak usia sekolah di SMP N 02 Songgom Kecamatan Songgom Kabupaten Brebes. Pengambilan lokasi penelitian berdasarkan banyaknya siswa dan asal siswa yang berasal dari desa yang berada dikecamatn songgom merata. Gambaran Karakteristis responden disajikan pada tabel 1 .

\begin{tabular}{|c|c|c|}
\hline \multirow{2}{*}{ Jenis } & \multicolumn{2}{|c|}{ Nilai } \\
\hline & Mean \pm SB & Min - Maks \\
\hline Umur (thn) & $14,2 \pm 2$ & $13-16$ \\
\hline $\operatorname{IMT}\left(\mathrm{kg} / \mathrm{m}^{2}\right)$ & $22,5 \pm 2,6$ & $17,8-27,4$ \\
\hline
\end{tabular}

Tabel 1 menunjukkan karakteristik subjek penelitian (Umur dan MT).Mean umur pada responden yaitu 14,2 tahun dengan umur terendah yaitu 13 tahun dan umur tertinggi yaitu 16 tahun. Indeks masa tubuh (IMT) responden memiliki rata rata 22,5 yang berarti memiliki status gizi yang baik dimana kisaran IMT responden antara 17,8 - 27,4

Tabel 2. Hubungan Kebiasaan Sarapan dengan Prestasi Belajar siswa

\begin{tabular}{|c|c|c|c|c|c|}
\hline \multirow{2}{*}{$\begin{array}{c}\text { Kebiasaan } \\
\text { Sarapan }\end{array}$} & \multicolumn{2}{|c|}{ Pertasi Belajar Siswa } & \multirow{2}{*}{$\begin{array}{c}\text { Total } \\
\mathbf{N}\end{array}$} & \multirow[b]{2}{*}{$\mathbf{R R}$} & \multirow[b]{2}{*}{$\mathbf{p}$} \\
\hline & $\frac{\text { Kurang }}{\mathbf{N}}$ & $\begin{array}{c}\text { Baik } \\
\mathbf{N}\end{array}$ & & & \\
\hline Kurang & 17 & 6 & 23 & 2,34 & $0,035^{*}$ \\
\hline Baik & 10 & 27 & 37 & & \\
\hline
\end{tabular}

Berdasarkan tabel 2 menunjukkan bahwa responden dengan kebiasaan sarapan pagi kategori kurang berjumlah 23 anak dengan 17 anak berprestasi kurang sedangkan yang 6 anak berprestasi baik. Kebiasaan sarapan pagi kategori baik berjumlah 37 anak dengan prestasi belajar siswa kategori kurang berjumlah 10 sedangkan 27 anak lainnya kategori baik dalam prestasi belajar siswa. Hasil analisis chi-square menunjukkan bahwa terdapat hubungan kebiasaan sarapan dengan prestasi belajar siswa di SMP N 02 Songgom terlihat dari nilai $\mathrm{p}<0,005$ yaitu P 0,035. Kekuatan hubungan antara kebiasaan sarapan dengan prestasi belajar siswa teerlihat dari nilai RR yaitu 2,34 yang artinya siswa yang memiliki kebiasaan sarapan yang baik memiliki peluang mendapatkan prestasi belajar siswa yang baik 2,34 kali lebih baik dibandingkan siswa yang kebiasaan sarapannya kurang.

Sarapan pagi merupakan saat makan yang paling penting dalam sehari. Makanan yang diasup di pagi hari bertugas mensuplai kadar gula darah. Setelah melewatkan satu periode berjam-jam tanpa makan, kadar gula darah dalam tubuh otomatis rendah. Padahal gula darah merupakan sumber utama energi otak dan sel darah. Oleh karena itu sarapan berfungsi untuk memulihkan cadangan energi dan kadar gula darah[4]. Di pagi hari kegiatan anak menuntut banyak gerak sehingga anak memerlukan energi untuk belajar dan berinteraksi dengan lingkungannya[5]. Dengan sarapan 
anak menjadi lebih bersemangat dan terlibat aktif dalam belajar. Makanan yang dikonsumsi sewaktu sarapan bukan hanya mengenyangkan tetapi juga bergizi lengkap dan seimbang. Sarapan yang baik dan memenuhi criteria gizi adalah dengan menyuplai karbohidrat (55-65\%), protein (12-15\%), lemak (24-30\%) serta vitamin dan mineral yang bisa diperoleh dari sayur dan buah[6]. Kadar gula darah yang didapatkan dari sarapan akan dirubah menjadi energi melalui proses metabolisme. Hasil dari metabolisme ini akan digunakan oleh sel-sel tubuh untuk menjalankan fungsinya. Sehingga pada akhirnya tubuh bisa menjalankan berbagai macam aktifitas mulai dari berpikir, bekerja, berlari sampai mengerjakan aktifitas sehari-hari lainnya. Pada usia sekolah, anak-anak memerlukan banyak nutrisi untuk tumbuh dan berkembang sesuai dengan tahap perkembangannya. Nutrisi yang didapatkan saat sarapan juga mempunyai peran penting dalam pertumbuhan dan perkembangan anak. Gula darah yang dihasilkan juga akan digunakan oleh selsel tubuh untuk tumbuh dan berkembang sesuai dengan tahap perkembangan usia anak. Penelitian ini sejalan dengan penelitian yang dilakukan oleh Elda pada 164 anak yang dijadikan sampel yaitu terdapat hubungan antara kebiasaan sarapan dengan prestasi belajar siswa[7].

Tabel 3. Hubungan Status Gizi dengan Prestasi Belajar siswa

\begin{tabular}{|c|c|c|c|c|c|}
\hline \multirow[b]{2}{*}{ Status Gizi } & \multicolumn{2}{|c|}{ Pertasi Belajar Siswa } & \multirow{2}{*}{$\begin{array}{c}\text { Total } \\
\mathbf{N}\end{array}$} & \multirow[b]{2}{*}{$\mathbf{R R}$} & \multirow[b]{2}{*}{$\mathbf{p}$} \\
\hline & $\begin{array}{c}\text { Kurang } \\
\mathbf{N}\end{array}$ & $\begin{array}{c}\text { Baik } \\
\mathbf{N}\end{array}$ & & & \\
\hline Normal & 22 & 29 & 51 & 1,56 & $0,045^{*}$ \\
\hline Overweight & 6 & 3 & 9 & & \\
\hline
\end{tabular}

Berdasarkan tabel 3 menunjukkan bahwa responden dengan status gizi normal berjumlah 51 anak dengan 22 anak berprestasi kurang sedangkan yang 29 anak berprestasi baik. Status Gizi pada kategori overweght berjumlah 9 anak dengan prestasi belajar siswa kategori kurang berjumlah 6 sedangkan 3 anak lainnya kategori baik dalam prestasi belajar siswa. Hasil analisis chi-square menunjukkan bahwa terdapat hubungan status gizi dengan prestasi belajar siswa di SMP N 02 Songgom terlihat dari nilai $\mathrm{p}<0,005$ yaitu $\mathrm{P} 0,045$. Kekuatan hubungan antara status gizi dengan prestasi belajar siswa teerlihat dari nilai RR yaitu 1,56 yang artinya siswa yang memiliki status gizi normal memiliki peluang mendapatkan prestasi belajar siswa yang baik 1,56 kali lebih baik dibandingkan siswa yang kebiasaan sarapannya kurang.

Siswa yang memiliki status gizi kurang atau kekurangan gizi akan menyebabkan terjadinya perubahan metabolisme pada anak yang berdampak pada kemampuan kognitif dan kemampuan otak anak. Hal tersebut dikarenakan kurangnya asuoan pada anak seperti kekurangan energi protein, akan berefek pada fungsi hippocampus dan korteks dalam membentuk dan menyimpan memori[8]. Status gizi kurang menyebabkan kemampuan kognitif dan perkembangan IQ terhambat sebagai akibat dari perkembangan otak yang tidak sempurna sehingga kemampuan belajar terganggu yang berimbas pada prestasi belajar siswa[9]. Penelitian ini sejalan dengan penelitian yang dilakukan oleh Rosita, 2014 yang menyatakan bahwa terdapat hubungan antara status gizi dengan prestasi belajar siswa[10].

\section{KESIMPULAN}

Terdapat hubungan kebiasaan sarapan $(\mathrm{P}<0,005)$ dan status gizi $(\mathrm{p}<0,005)$ terhadap prestasi belajar siswa di SMP N 02 Songgom. Kekuatan hubungan antara kebiasaan sarapan dengan prestasi belajar siswa sebesar 2,34 yang artinya siswa yang memiliki kebiasaan sarapan yang baik memiliki peluang mendapatkan prestasi belajar siswa yang baik 2,34 kali lebih baik dibandingkan siswa yang kebiasaan sarapannya kurang. Kekuatan hubungan antara status gizi dengan prestasi belajar siswa sebesar 1,56 yang artinya siswa yang memiliki status gizi normal memiliki peluang mendapatkan prestasi belajar siswa yang baik 1,56 kali lebih baik dibandingkan siswa yang kebiasaan sarapannya kurang. 


\section{DAFTAR PUSTAKA}

[1] M. Studer et al., "Factors affecting cognitive outcome in early pediatric stroke," Neurology, 2014, doi: 10.1212/WNL.0000000000000162.

[2] H. Yudi, "Hubungan Faktor Sosial Budaya dengan Status Gizi Anak usia 6-24 bulan di Kecamatan Medan Area Kota Medan tahun 2008," Univ. Sumatera Utara, 2008.

[3] Sukiniarti, "Kebiasaan Makan Pagi Pada Anak Usia SD dan Hubungannya dengan Tingkat Kesehatan dan Prestasi Belajar," ISSN:1442-3750, 2015.

[4] MCA Indonesia, "Stunting dan Masa Depan Indonesia," Millenn. Chall. Acc. - Indones., 2013.

[5] L. Faizah and T. Rifameutia, "Sojourner Students' Adjustment: Do They Need to Lower Their Normative Achievement Goal Orientation to Remain Confident and Survive?," Makara Hum. Behav. Stud. Asia, 2019, doi: 10.7454/hubs.asia.1120119.

[6] I. S. Anzarkusuma, E. Y. Mulyani, I. Jus'at, and D. Angkasa, "Status gizi berdasarkan pola makan anak sekolah dasar di kecamatan Rajeg Tangerang," Indones. J. Hum. Nutr., 2014.

[7] E. Khalida, E. Fadlyana, and D. H. Somasetia, "Hubungan Kebiasaan Sarapan dengan Prestasi Belajar dan Fungsi Kognitif pada Anak Sekolah Dasar," Sari Pediatr., 2016, doi: 10.14238/sp17.2.2015.89-94.

[8] . I. O. S., "Evaluation of Energy and Micronutrients Intake of Nigerian Adolescent Females: A Case Study of Institutionalized Secondary Schools in Akure South Local Government Area, Ondo State, Nigeria," Pakistan J. Nutr., 2004, doi: 10.3923/pjn.2004.250.253.

[9] J. M. Perkins, R. Kim, A. Krishna, M. McGovern, V. M. Aguayo, and S. V. Subramanian, "Understanding the association between stunting and child development in low- and middle-income countries: Next steps for research and intervention," Social Science and Medicine. 2017, doi: 10.1016/j.socscimed.2017.09.039.

[10] R. H. Sa'adah, R. B. Herman, and S. Sastri, "Hubungan Status Gizi dengan Prestasi Belajar Siswa Sekolah Dasar Negeri 01 Guguk Malintang Kota Padangpanjang," J. Kesehat. Andalas, 2014, doi: 10.25077/jka.v3i3.176. 